\title{
Resistance of Rebo Pungkasan Traditional Ceremony in Industrial Revolution 4.0
}

\author{
Wahyu Surbono ${ }^{1}$ Sutiyono $^{2}$
}

\author{
${ }^{1}$ Univeritas Negeri Yogyakarta, Yogyakarta, Indonesia \\ ${ }^{2}$ Univeritas Negeri Yogyakarta, Yogyakarta, Indonesia \\ *Corresponding author. Email: wahyusurbono@gmail.com
}

\begin{abstract}
Rebo pungkasan is one of the cultural heritages of Pendoworejo village located in Kulon Progo regency. This traditional ceremony survives because as a local wisdom, it can integrate members of societies into one although it faces problems in this 4.0 Industrial Revolution. Nowadays, the products of the era profoundly affect various aspects of human life including the aspects of technology, industry, economy, and culture. The traditional ceremony experiences regeneration problems because of the emergence of the Industrial Revolution. This study aims to investigate the efforts of Pendoworejo societies to resist the changes which go along with the Industrial Revolution. It is a qualitative descriptive study that uses qualitative methods to collect data through observations, interviews, and documentation. The interactive data analysis was conducted, and it was found that: (1) Jathilan has an important role in attracting people's attention during rebo pungkasan traditional ceremonies, and (2) to cherish the tradition, formal education including elementary schools in Pendoworejo Village should ask their students take part in the traditional ceremony.
\end{abstract}

Keywords: Jathilan, Rebo Pungkasan, resistance

\section{INTRODUCTION}

Pendoworejo is one of the villages in Kulon Progo, Yogyakarta Special Region, which has various cultures in the forms of customary ceremony, art, and ritual. Customary ceremony is one of the most popular cultures in Pendoworejo Village, because it is held annually. Usually, the customary ceremonies conducted in the village have a relation with the agriculture field such as bersih desa (Javanese traditional ceremony to give offerings to village spirits), ruwatan (ritual manifestation of gratitude to God Almighty for everything that has been obtained from the earth), kupatan (Javanese tradition conducted after Eid AlFitr), and rebo pungkasan. Therefore, the local society is named as a farming community viewed from ceremony orientation, profession, and geographic location in which almost $70 \%$ of the village is the farming area.

Based on the customary ceremony carried out in the village, rebo pungkasan has the biggest scale in terms of the implementation, because it involves 17 hamlets in the village. Socio-historical ties with a Pendoworejo Village's ancestor named Mbah Bei became a source of understanding for citizens to create social integration. The correlation of stories between ancestors and rebo pungkasan is still continuously transmitted through generations to preserve the ceremonies and cultural identity of Pendoworejo Village.

Based on the story developed in Pendoworejo Village, Mbah Bei was one of the descendants of the King Brawijaya V who fled during the collapse of the Majapahit kingdom. During his escape, Mbah Bei stopped in the Pendoworejo Village area with his two courtiers named Kyai Somoito and Kyai Diro. Both of them were his people who served as the horse keepers and escorted Mbah Bei's journey while running away. At that time, Mbah Bei discovered a phenomenon where the residents of Pendoworejo Village had difficulties in obtaining springs for agricultural and plantation irrigation. To overcome this problem, Mbah Bei gave an idea to the residents to build a dam known as the Kayangan dam.

Kayangan Dam is an iconic building for the Pendoworejo villagers because it has deep meaning related to community life. In the history, it is said that Mbah Bei is a figure who has a high spiritual ability that can dissapear (moksa) when performing meditation in the middle of the dam. The people at that time believed that Mbah Bei had headed for the highest peak in human life, namely Kayangan. Therefore, the name of the dam which is the place of ceremony and life source for the residents is obtained based on the events of Mbah Bei's moksa to Kayangan.

Kayangan Dam, history of ancestors, and changes in agricultural life become the basis for the formation of the social practices of Pendoworejo Villagers, manifested in 
the rebo pungkasan traditional ceremony. The historical experience [12] of a society shows relations among people and is an important part of maintaining its existence through customary, religious, economic, and social activities. Historical similarities rooted in past events are the main capital of the residents in creating the rebo pungkasan traditional ceremony which has meaning as an expression of gratitude for the agricultural fertility on the existence of the Kayangan Dam. On the monumental side, rebo pungkasan is a moment of Mbah Bei's merit that is considered to have a major role in the sustainability of the agricultural life of the Pendoworejo residents.

Rebo pungkasan has an implementation procedure that must be carried out in accordance with the legitimacy of its predecessors. The procedure includes the time and place of the ceremony. The last Wednesday in the Sapar month is set as the schedule of the ceremony. Meanwhile, the Kayangan dam is the only place for the ceremony that cannot be replaced or moved to another place. This shows that the local residents still hold fast to traditions handed down from generation to generation and served as guidelines for the ceremony implementation.

The rebo pungkasan traditional ceremony runs in an organized manner because it has fixed and clear stages. The first stage includes a brief description of the history of the rebo pungkasan and the Kayangan dam carried out by the Tribal Chef. The second stage is prayers in Islam using Javanese conducted by the local Rois people. The third stage is the peak of the ceremony with an activity of eating together with all the residents of Pendoworejo Village. The food served is brought by the residents of 17 hamlets in the Village and must come from earth products such as farming, plantation, and livestock. In addition to the procedures and stages of the ceremony that are still maintained by the residents of Pendoworejo Village, rebo pungkasan also has an aesthetic value, namely the Jathilan art performances held in the Kayangan dam area. This is in line with the characteristics of traditional ceremonies that have several aspects, namely aesthetics, ritual-religious, and mutual cooperation [7].

The Jathilan art performance in the rebo pungkasan traditional ceremony is also held in Geneng Village, Klaten Regency. In that place, puppet performances in the village cleansing ceremony serve as a medium to raise people awareness about the importance of rice plants in human life [9]. It is different from the involvement of Jathilan art in the rebo pungkasan traditional ceremony in Pendoworejo Village which is not yet clearly known about the reasons and functions. That is because in general, Jathilan art is considered as community entertainment. Meanwhile, the traditional ceremony has religious and sacred values. Religious values and sacredness in the traditional ceremonies are still maintained by Pendoworejo Village community as a form of resistance.
As the efforts, Pendoworejo Village community carries out open and closed resistances. The efforts made by the community in maintaining the rebo pungkasan traditional ceremony is an interesting thing. That is caused by a problem of the social life to deal with the Industrial Revolution 4.0 towards the development of modernization era civilization which is extraordinarily real in Indonesian society. The Industrial Revolution 4.0 has a profound impact on changes in various aspects of human life such as technology, industry, economy, and culture. As what happens in the lives of the Pendoworejo Village people, various attacks of the Industrial Revolution 4.0 products begin to flock, come, and go in the daily life of the Pendoworejo Village community. However, the majority of Pendoworejo Village people tend to be able to select and sort out various things included in the daily routine of people's lives. Another thing is the point of view of some Pendoworejo Village people who are determined to always preserve the traditional ceremonies for generations in the rapid development of modernization civilization. The preservation of the rebo pungkasan traditional ritual through the resistance among generations cannot be separated from the role of Jathilan art as an attraction in the traditional ceremony. Meanwhile, the resistance efforts were also made through regeneration in the scope of formal education by involving elementary school students throughout the village of Pendoworejo to participate in the ceremonial procession

\section{RESEARCH METHOD}

The method used in this was descriptive qualitative research. Through this qualitative method, an understanding on complexity of a cultural and community phenomenon is obtained. Qualitative research [4] is an approach and method that has a use value to study a phenomenon. The significance obtained through this qualitative research depends on the research design, such as observation documentations of a culture, new insights, understanding of individual and social complexity, and criticism of social order.

Pendoworejo Village is one of the villages in Kulon Progo which has a cultural diversity. Even though they have many sources of cultural knowledge, in that village the documentation of cultural activities is rarely found. Therefore, Pendoworejo Village, Sub-District of Girimulyo, Kulon Progo Regency was selected as a research location with the object study of Jathilan art performance in the rebo pungkasan traditional ceremony and the regeneration of it in the scope of formal education. The research subject consisted of the local residents including Tribal Chief, Rois people, Jathilan performers, local traders, and farmers. 
In qualitative research, the researchers became the main instrument in collecting data through field observations and interaction with the subjects and objects under study. This is expressed by Mohajan [10] that researchers are the main instruments in collecting and analyzing data. The researchers must interact with the subject and object of the study to observe behaviors in order to build abstractions, concepts, and theories. Before conducting research in Pendoworejo Village, the researchers prepared audiovisual recorders to document the ceremonial procession, and conduct interviews, and noted the results of observations such as the involvement of community members (traders, farmers, tourists, etc.) both at the beginning of the ceremony procession and the end of Jathilan art performance.

Data collection techniques in this study were carried out in three ways namely; observation, interview, and documentation. The data were analyzed using a MilesHuberman interactive data analysis including data reduction, data display, and conclusion drawing. Data reduction is the first process that has a pattern for sorting, selecting, and simplifying data. Data display refers to an activity of presenting data or information deemed to have the potential to draw conclusions. Conclusion drawing [10] is carried out to formulate data leading to the data validation stated in the research report, but it depends on the estimation of time of the study and data collection, which has been considered to reach a level of saturation. the potential to draw conclusions. Conclusion drawing [10] is carried out to formulate data leading to the data validation stated in the research report, but it depends on the estimation of time of the study and data collection, which has been considered to reach a level of saturation.

\section{DISCUSSION}

Pendoworejo Village is not far from the center of Kulon Progo Regency, Wates District. It is one of the rural areas, but it has gradually become a modern area in terms of the daily routine of the community. This is due to the strategic position of this village which is located not far from the downtown. This is also shown by the variety of needs in the economic, health and tourism aspects of this region. Therefore, the community life is inseparable from the dominance of products in the era of the Industrial Revolution 4.0. The position of society can be said as a passive consumer of these products. This becomes a threat to the existence of folk culture in this village among generations.

Today, the dominance of the Industrial Revolution 4.0 products in Pendoworejo can be seen from the daily routine of people's lives. Representation of the products causes blurred values, namely the boundary between high and low values. The representation of art works in the era is highly related to the profit so that pragmatic values are ignored.

The rebo pungkasan traditional ceremony is one of the products or forms of folk culture that has survived the Industrial Revolution 4.0. The customary ceremony is not oriented to profitability and commercialization. The implementation of it is non-profit and is a form of public awareness to preserve traditional culture for generations. This is contrary to the representation of art products in the Industrial Revolution 4.0 era.

The resistance of the traditional ceremony is shown by the existence and continuity of the ceremony carried out by the Pendoworejo community until nowadays. Conducting the ceremony annually is one of the resistance forms by the Pendoworejo community towards the dominance Industrial Revolution 4.0 products used in the people's lives. Rebo pungkasan has an implementation procedure that must be carried out in accordance with the legitimacy of its predecessors. The procedure includes the time and place of the ceremony. The last Wednesday in the Sapar month is set as the time of the ceremony, and the Kayangan dam is the only place for the ceremony that cannot be replaced or moved to another place. This shows that the local residents still hold fast to traditions handed down from generation to generation and served as guidelines for the ceremony implementation.

The concept proposed by Scott [5] is open resistance (public transcript) and closed resistance (hidden transcript) Open resistance includes organic, systemic, and cooperative, selfless, revolutionary consequences, and the idea of negating the basis of domination. The first concept of open resistance is organic, systemic, and cooperative. The first concept of open resistance can be seen through the implementation of the rebo pungkasan traditional ceremony which continues to be preserved in an organizational system. The implementation of this traditional ceremony has been organized by the Pendoworejo community. This is indicated through the task division among the residents in accordance with the agreed work system in the management and technical implementation of the traditional ceremony.

The second concept of open resistance is selflessness. In this second concept, it can be seen from the main purpose of the implementation, which is not about profit (commercialization). The implementation of this traditional ceremonial ceremony is a form of community awareness of Pendoworejo Village towards the balance of nature and humans that must be maintained. The implementation of this traditional ceremony is based on a calling, the sincerity of the community, and is not concerned with personal interests. Therefore, the implementation of the ceremony prioritizes teamwork, so that a community member does not work independently, but relies on other community members. 
The third concept of open resistance is revolutionary consequences. It is related to the social mission of the community and changes in the people's lives in a better direction. The social mission contained in the traditional ceremony is marked by the existence of mutual cooperation, harmony, tolerance, and familiarity among the community members. Therefore, the rebo pungkasan traditional ceremony is still carried out by the entire community of Pendoworejo Village. In addition, the implementation of the ceremony is means and efforts made by the community to establish better social relations among citizens. This is due to the anticipation of the residents regarding nature and social changes that occur in the people's lives from negative influences having a major impact with the emergence and existence of art products in the Industrial Revolution 4.0.

The fourth concept of open resistance is the idea of negating the basis of domination. It is related to how the local community is able to maintain the traditional ceremony in the routine of people's lives with the function of the community itself. The function of art itself [8] includes personal entertainment, rituals, and aesthetic presentations. The main function of the implementation of folk culture (rebo pungkasan traditional ritual ceremony) includes the ritual and religious interests of the community towards the balance between nature and humans, which is still maintained until now. The relationship between ritual and religious functions to the idea of negating the basis of domination, namely the existing ritual aspects, is an idea or an effort to negate the basis of domination of art products in the Industrial Revolution 4.0. That is because the dominance of art products in Industrial Revolution 4.0 greatly affects the routine of Pendoworejo community. The rebo pungkasan traditional ceremony itself contains many positive values that exist in its implementation. Positive values beneficial to the community are intended to negate the basis impact of the dominance of new art products along with the value and norm shift from the existence of the products.

Meanwhile, a closed resistance concept proposed by Scott [5] is disorganized, unsystematic, individual, opportunistic and selfish, not revolutionary consequences, and accommodation to the domination system. The first concept of closed resistance is disorganized, unsystematic, and individual. It can be seen through the dominance of the Industrial Revolution era art products published by agents to the people of Pendoworejo Village. The dominance of these products often contains values and attitudes opposite to the existing norms and values in the daily lives. This type of closed resistance is noticed from the negative imaging of art products of the Industrial Revolution era, most of which contrast with Javanese cultural traditions and customs. This is much contrasted to the implementation of the rebo pungkasan traditional ceremony that contains positive values beneficial to the life of the Pendoworejo Village community.

The second concept of closed resistance is opportunistic and selfish. It is indicated by the rise of dominance of Industrial Revolution 4.0 art products consumed by the public. The community can be positioned as a passive member of the community who cannot fight the presence of the dominating products. However, the people of the village have their own understanding and point of view that the coming products are only taken for profit and will not affect their routine. The product benefits to the community are only considered as enjoyment. Meanwhile, the negative values presented from these products are ignored by the people of Pendoworejo Village. In other words, people have already raised awareness and ways of thinking forward; the community can select and sort out the products presented by agents in this industrial revolution 4.0.

The third concept of closed resistance is no revolutionary consequences. It can be seen from the chats or conversations carried out among residents of the Pendoworejo Village towards public awareness of the negative images of the products of the Industrial Revolution era 4.0. This is different from the implementation of the Reb rebo pungkasan traditional ceremony itself. It is an invitation to goodness, a form of respect for the ancestors and Mbah Bei, and an expression of gratitude to God for the balance of nature that is still maintained until today.

The fourth concept of closed resistance is accommodation to the domination system. It can be seen through the adaptation of the people of Pendoworejo Village to the emergence of new products. In other words, the traditional community who carries out the ceremony up to now is certainly inseparable from the presence of the Industrial Revolution 4.0 agents from the dominant class in the daily life cycle. Therefore, the people keep on trying to accommodate the emergence of various products. However, they still select and sort out the products that are very impactful and even strong with the negative values. Therefore, society does not directly accept the agents of the new era. The attitude shown by the Pendoworejo Village community is an effort to resist the influence and adverse effects of the Industrial Revolution 4.0 products produced by capitalists or market interests.

A real form of open and closed resistance has been carried out by the Pendoworejo Village community towards the emergence of products in the Industrial Revolution era 4.0. These products provide various impacts of enormous changes on various sides of human life such as; technology, industry, economy, and culture. Rebo pungkasan is one of the traditional ceremonies that cannot be separated from the influence of the new products. The tradition potential possessed by the traditional ceremony experiences a great disruption. The signs can be seen through the phenomenon 
of the difficulty of the residents to carry out the regeneration process. Therefore, the people of Pendoworejo Village make a resistance effort through the regeneration process. It is carried out by involving elementary school students throughout the village to participate in the traditional ceremonial procession.

The series of the ceremony processions also includes the performance of Jathilan art. It has a very important role in the attraction of the ceremony implementation. Indirectly, Jathilan art performance is also one of the resistance efforts of the rebo pungkasan traditional tradition. The resistance form of rebo pungkasan traditional ceremony through Jathilan arts and educational media are described as follows:

\subsection{Jathilan Art as the Identity Mark of the Rebo Pungkasan Traditional Ceremony}

Jathilan Art in quantity is the art highly demanded by the Pendoworejo Village community. It is based on the data on the cultural potential of Pendoworejo, namely 7 Jathilan art groups in the village. Therefore, it becomes a cultural identity for Pendoworejo Village. Jathilan art performance in the rebo pungkasan ceremony is a form of the cultural expression that cannot be found in daily life because it includes other cultural elements, namely traditional ceremonies.

In the ceremony context, rebo pungkasan is found not only in Pendoworejo Village, but also in other regions in the Yogyakarta Special Region. Wonokromo is one of the subdistricts in Yogyakarta that conducts rebo pungkasan. The ceremonial procession in Wonokromo also has similarities with it in Pendoworejo Village. This is responded by the residents of Pendoworejo Village to obtain information about the differences of rebo pungkasan in another place. Symbols are created by humans to respond to the environmental situation being faced in the form of symbolic expressions [3]. Pendoworejo residents use their cultural identity to achieve this by involving one of the cultural elements, namely Jathilan art as a mark of ceremonial identity.

The creation of the Jathilan art symbol at the rebo pungkasan traditional ceremony took place in 2011. The customization of the performance carried out in each of the ceremonies becomes a unique feature. That is because the performance took place in the dam area; it is not conducted in the field like Jathilan art performances in general. The art is used as a medium to fulfill the existential needs of Pendoworejo Village and rebo pungkasan in order to have characteristics in its culture. It is a cultural strategy planned in an organized manner in strengthening social conformity. Therefore, Jathilan art in the rebo pungkasan traditional ceremony is said to contain social functions that are able to strengthen the identity and integrity of the supporting community [1].

As a farming community, Pendoworejo Village residents have artistic creativity which for most people is considered to have an aesthetic function specifically to meet inner needs only. However, it is not widely realized that art also has other functions in human life. For instance, the Jathilan art in the rebo pungkasan traditional ceremony does not function as mere entertainment like the performance of it elsewhere. It functions as a means of sanctity in supporting the series of ceremonial processions. Indirectly, Jathilan art is an identity in the rebo pungkasan traditional ceremony procession.

Jathilan, performed by the Javanese village farmer community, functions as a media to legitimize the existence and preserve the identity. This is also part of their cultural expression [6]. As explained by Rohidi [11], culture can be defined as follows: (1) life guidelines used as a blueprint or comprehensive design for the supporting community; (2) symbol systems, the appropriation of meanings and cognitive models transmitted through symbolic codes; and (3) adaptive strategies to preserve and develop one's life in dealing with the environment and resources [2].

Jathilan art performed in the closing of the rebo pungkasan ceremony is included in the type of classical Jathilan art. This is evidenced by the traditional musical instruments played by musicians such as; gong, bendhe, angklung, kecer, and kendhang. Effectiveness and field conditions become a major consideration in the selection of the musical instruments. This contrasts with Jathilan's new artistic creations using modern musical instruments.

Jathilan art in the traditional ceremony which is very different from other places or Jathilan art in general becomes distinctive characteristics or uniqueness. This can be seen from the enthusiasm of Pendoworejo Village residents, local tourists, and foreign tourists who experience an increase in number from year to year to participate in a series of the ceremonial processions. These facts show that the rebo pungkasan traditional ceremony still exists and is resistant until the present.This is certainly inseparable from the role of Jathilan art itself. It has become an identity for the rebo pungkasan traditional ceremony held in Pendoworejo Village. The implementation rules of the Jathilan art in the ceremony are still resistant until today, which is marked by the absence of changes in the rules and stages of the ancestors. It is also one of the factors attracting the community, local, and foreign tourists to continue to participate in the implementation of it.

\subsection{Trade and Education Media}


Jathilan art performance in the rebo pungkasan traditional ceremony procession has a positive impact on the lives of Pendoworejo Village residents. The physical and nonphysical potential such as natural beauty and economic creativity can be put to good use by the local community. Jathilan art and rebo pungkasan are used as the main capital for several sectors including tourism and economy. In addition to utilizing water from the Kayangan dam for daily needs, currently Pendoworejo villagers are also thinking of exploring the natural beauty potential of the dam based on its historical side. One of the goals to be achieved is to improve the local resident economy. Mbah Bei is a person who has an idea to build the Kayangan dam. Understanding the function associated with the existence of a type of art in society is not merely a creative activity, but rather usability. It means that the existence of art in society has a use value and products that provide benefits to the community, especially in maintaining social sustainability [13]. The Kayangan Dam is currently used as an attraction in the ceremony through myth, function, and history. It tells visitors stories about the meaning of the dam for the lives of Pendoworejo Village residents. The discourse became one of the centers of interest so that the community was attracted to attend the Rebo Pungkasan Kembul Sewu Dulur ceremony. This then becomes an opportunity for local residents to drive the pace of economy by making a variety of snacks.

In addition to having an impact on the economic sector of the Pendoworejo Village community, the implementation of rebo pungkasan also has an impact on the education sector. This can be seen from the enthusiasm of elementary school students in Pendoworejo Village who take part in the traditional ceremony pocession every year. Indirectly, the implementation of rebo pungkasan traditional has given birth the values of kindness. Good values in the tradition have started to be instilled in society from an early age. The facts in the rebo pungkasan implementation are the implications of the regeneration process carried out by the local community. The regeneration process is carried out from generation to generation as a form of resistance in preserving traditional culture in the modernization and the Industrial Revolution 4.0

\section{CONCLUSION}

Pendoworejo Village, one of the villages in the Kulon Progo, Yogyakarta, has cultural diversity through various forms of traditional ceremonies, arts, and rituals. Traditional ceremonies are one of the most popular cultural elements in Pendoworejo Village, because it is annually carried out. On average, the traditional ceremonies conducted are linked to the agriculture fields such as village cleansing, ruwatan, kupatan, and rebo pungkasan.
Rebo pungkasan has procedures for implementation that must be carried out in accordance with the legitimacy of its predecessors. The procedure includes the time and place of the ceremony. The last Wednesday in the Sapar month is set as the time of the ceremony. Furthermore, the Kayangan dam is the only place for the ceremony that cannot be replaced or moved to another place. This shows that the local residents still hold fast to traditions handed down from generation to generation and served as guidelines for the ceremony implementation.

The rebo pungkasan traditional ceremony is one of the forms of folk culture that has survived the Industrial Revolution 4.0. The customary ceremony is not oriented to profitability and commercialization. The implementation of it is non-profit and is a form of public awareness to preserve traditional culture for generations. This is contrary to the representation of art products in the Industrial Revolution 4.0 era.

The rebo pungkasan traditional ceremony is one of the products or forms of folk culture that survives the Industrial Revolution 4.0. The customary ceremony of the rebo pungkasan is not oriented to profitability and commercialization. However, the implementation of the rebo pungkasan traditional ceremony is non-profit and is a form of public awareness to preserve traditional culture for generations. This is contrary to the representation of products in the Industrial Revolution 4.0 era. Efforts carried out by the Pendoworejo Village community in dealing with the products of Industrial Revolution 4.0 are made through closed and open resistance.

A real form of open and closed resistance has been carried out by the Pendoworejo Village community towards the emergence of products in the Industrial Revolution 4.0. These products provide various impacts of enormous changes on various sides of human life such as technology, industry, economy, and culture. Rebo pungkasan is one of the traditional ceremonies that cannot be separated from the influence of the new products. Tradition potential possessed by the ceremony experiences a great disruption. The signs can be seen through the phenomenon of the residents' difficulties to carry out the regeneration process. Therefore, the people of Pendoworejo Village make a resistance effort through the regeneration process. It is carried out by involving elementary school students throughout the village to participate in the traditional ceremonial procession.

On the other hand, the procession series of rebo pungkasan also involves Jathilan art. It has a very important role in the attraction of the traditional ceremony. Indirectly, Jathilan art performance is also one of the efforts of the Pendoworejo Village community to do resistance of rebo pungkasan. In the end, to find out further the resistance efforts by the Pendoworejo Village community requires an extensive study. The author realizes that there are still many things that cannot be explained in detail including the resistance of the rebo pungkasan traditional ceremony in the Industrial Revolution 4.0, so that further research is needed. Hopefully, this article can provide significance for society as a whole. 


\section{REFERENCES}

[1] Irianto, Agus Maladi. "Mengemas Kesenian Tradisional Dalam Bentuk Industri Kreatif: Studi Kasus Kesenian Jathilan [Adjusting Traditional Arts in the Form of Creative Industries: A Case Study of Jathilan Art]." HUMANIKA Vol. 22 No. 2 (2015) ISSN 1412941822.2 (2015).

[2] Irianto, Agus Maladi. "The Development of Jathilan Performance as an Adaptive Strategy Used by Javanese Farmers." Harmonia: Journal of Arts Research and Education 16.1 (2016): 38-48.

DOI: https://doi.org/10.15294/harmonia.v16i1.5213

[3] Triguna, Ida Bagus Gede Yudha, and Ida Bagus Gde. "Teori Tentang Simbol [The Theory of Symbols]." Denpasar: Widya Dharma (2000).

[4] Saldana, Johnny. Fundamentals of qualitative research. OUP USA, 2011.

[5] Scott, James C. Domination and the arts of resistance: Hidden transcripts. Yale university press, 1990.

[6] Koentjaraningrat. "Kebudayaan mentalitas dan pembangunan [Cultural of Mentality and Development].” Jakarta: Gramedia Pustaka Utama (1994).

[7] Sutiyono. Paradigma pendidikan seni di Indonesia [Arts Education Paradigm in Indonesia]. Yogyakarta: UNY Press (2012).

[8] Soedarsono. "Pertunjukan seni Indonesia dari perspektif politik, sosial, dan ekonomi [Indonesia Performance Arts From a Political, Social and Economic Perspective].” Yogyakarta: Gadjah Mada University Press (2003).

[9] Sutiyono, Sutiyono, and Bambang Suharjana. "Pemuliaan Tanaman Padi melalui Pertunjukan Wayang Kulit dalam Upacara Bersih Desa di Geneng, Trucuk, Klaten, Jawa Tengah [Rice Plant Breeding through Wayang Kulit Performance in Bersih Desa in Geneng, Trucuk, Klaten, Central Java] ." Mudra Jurnal Seni Budaya 33.2 (2018): 263-269.

DOI: https://doi.org/10.31091/mudra.v33i2.267

[10] Mohajan, Haradhan Kumar. "Qualitative research methodology in social sciences and related subjects." Journal of Economic Development,
Environment and People 7.1 (2018): 23-48. http://jedep.spiruharet.ro

[11] Rohidi, Tjetjep Rohendi. "Metodologi penelitian seni [Art Research Methodology]." Semarang: Cipta Prima Nusantara 75 (2011): 116-121.

[12] Uhi, Jannes Alexander. "Filsafat Kebudayaan [Cultural Philosophy]." Yogyakarta: Pustaka Pelajar (2016).

[13] Kuswarsantyo, Kuswarsantyo. "Seni Jathilan Dalam Dimensi Ruang Dan Waktu [The Art of Jathilan in the Dimensions of Space and Time]." Jurnal Kajian Seni 1.1: 48-59. DOI: https://doi.org/10.22146/art.5875 